\title{
PENGARUH SKEPTISISME PROFESIONAL, ETIKA, TIPE KEPRIBADIAN, KOMPENSASI, DAN PENGALAMAN PADA PENDETEKSIAN KECURANGAN
}

\author{
Kadek Gita Arwinda Sari ${ }^{1}$ \\ Made Gede Wirakusuma ${ }^{2}$ \\ Ni Made Dwi Ratnadi ${ }^{3}$
}

\author{
${ }^{1}$ Fakultas Ekonomi dan Bisnis Universitas Udayana, Bali, Indonesia \\ e-mail: gita_arwinda@yahoo.com \\ ${ }^{2}$ Fakultas Ekonomi dan Bisnis Universitas Udayana, Bali, Indonesia \\ ${ }^{3}$ Fakultas Ekonomi dan Bisnis Universitas Udayana, Bali, Indonesia
}

\begin{abstract}
ABSTRAK
Penelitian ini bertujuan untuk mendapatkan bukti empiris pengaruh skeptisisme profesional, etika, tipe kepribadian, kompensasi, dan pengalaman pada pendeteksian kecurangan. Kemampuan pendeteksian kecurangan yang dilakukan oleh auditor dapat dipengaruhi oleh karakteristik yang dimiliki oleh auditor, baik karakteristik personal auditor maupun karakteristik dari luar personal auditor. Teori atribusi digunakan sebagai kajian teoritis dalam penelitian ini. Sampel dalam penelitian ini sebanyak 66 orang yang dipilih menggunakan teknik purposive sampling. Analisis regresi linear berganda digunakan dalam penelitian ini sebagai teknik analisi data. Sebelum melakukan analisis regresi dilakukan pengujian instrumen penelitian dan uji asumsi klasik untuk keakurasian hasil analisis regresi.Hasil analisis menunjukkan, skeptisisme profesional, etika, kompensasi, dan pengalaman berpengaruh positif pada pendeteksian kecurangan, sedangkan tipe kepribadian tidak berpengaruh pada pendeteksian kecurangan.
\end{abstract}

Kata Kunci: Skeptisisme profesional, Etika, Tipe Kepribadian, Kompensasi, Pengalaman, Pendeteksian Kecurangan.

\begin{abstract}
This research aims to obtain empirical evidence of the influence of professional skepticism, ethics, personality types, compensation, and experience in the detection of fraud. The ability of detecting fraud carried out by the auditor can be affected by the characteristics possessed by the auditor, whether Auditors personal characteristics as well as characteristics of beyond personal auditor. The theory of attribution used as theoretical studies in this research. The sample in this study as many as 66 people were selected using a purposive sampling technique. Multiple linear regression analysis used in this study as data analysis techniques. Before doing the regression analysis conducted testing research instrument and test the assumptions of classical regression analysis results for accuracy.The results of the analysis showed, the professional skepticism, ethics, compensation, and experience the positive effect on the detection of fraud, while personality type has no effect on the detection of fraud.

Keywords: Professional Skepticism, Ethics, Personality Types, Compensation, Experience, The Detection of Fraud
\end{abstract}

\section{PENDAHULUAN}


Kd. Gita A.S., Md Gd Wirakusuma dan Ni Md D. Ratnadi Pengaruh Skeptisisme...

Kinerja perusahaan salah satunya dapat dinilai dari informasi yang terkandung dalam laporan keuangan perusahaan. Laporan keuangan juga menyediakan berbagai informasi yang dibutuhkan oleh berbagai pihak untuk membuat suatu keputusan sesuai dengan kepentingannya masing - masing. Laporan keuangan yang berkualitas adalah laporan keuangan yang tidak mengandung risiko informasi. Risiko informasi yang dimaksud ialah kemungkinan bahwa informasi yang terkandung dalam laporan keuangan tidak benar, tidak lengkap maupun mengandung bias (Fransiska dan Fatmawati, 2015). Untuk mengurangi risiko informasi tersebut dibutuhkan audit laporan keuangan yang berperan untuk mengurangi risiko informasi yang terkandung dalam laporan keuangan. Salah satu penyebab risiko informasi ialah perbedaan kepentingan antara pengguna dengan penyusun laporan keuangan. Oleh sebab itu, audit laporan keuangan perlu dilakukan oleh pihak independen yaitu auditor untuk mendeteksi adanya kecurangan dalam laporan keuangan agar menghasilkan informasi yang berkualitas. Banyaknya Kantor Akuntan Publik ternama di dunia termasuk Indonesia yang terlibat kasus manipulasi laporan keuangan menunjukkan bahwa laporan keuangan saat ini masih memiliki kualitas informasi yang rendah. Salah satu diantaranya adalah kasus Enron Corp terkait manipulasi pembukuan yang dilakukan dan melibatkan kantor akuntan publiknya. Kasus manipulasi keuangan yang terjadi di Indonesia dengan melibatkan kantor akuntan publik, diantaranya adalah kasus PT. Kimia Farma yang melakukan mark up dan kasus Bank Lippo yang memiliki laporan keuangan ganda. Auditor terlambat 
mengetahui ketidakberesan yang dilakukan manajemen perusahaan menjadi kesalahan auditor dalam kasus tersebut.

Keterlibatan auditor dalam banyaknya kasus manipulasi membuat profesi akuntan dipertanyakan dan menjadi sorotan oleh pembuat kebijakan dan masyarakat. Sebagai pihak independen, akuntan publik memiliki tanggungjawab untuk memberikan penilaian yang sebenarnya atas laporan keuangan yang disajikan oleh manajemen perusahaan. Auditor harus memiliki keyakinan memadai, bahwa salah saji material tidak terdapat dalam laporan keuangan yang disebabkan oleh kesalahan maupun kecurangan, sebagai dasar pemberian opini audit.

Skeptisisme profesional auditor yang rendah merupakan salah satu penyebab gagalnya auditor melakukan pendeteksian kecurangan (Beasley et al. 2001, dalam Novianty, 2008). Carpenter, Durtschi dan Gaynor (2002) juga mendukung pernyataan tersebut, bahwa auditor yang lebih skeptis akan mampu melakukan pendeteksian kecurangan pada tahap perencanaan audit, dan akan meningkatkan pendeteksiannya pada tahap audit berikutnya. Auditor yang melaksanakan tugas sesuai dengan standar dan menjunjung tinggi norma agar kualitas audit tetap terjaga adalah auditor yang memiliki skeptisisme profesional, (Gusti dan Ali, 2008)

Pengalaman juga sangat memengaruhi kemampuan auditor dalam melakukan pendeteksian kecurangan. Auditor dapat meningkatkan pengetahuannya mengenai kecurangan dan kekeliruan dapat dibantu oleh pengalaman yang dimilikinya (Tirta dan Solihin, 2004). Dampak negatif dapat 
Kd. Gita A.S., Md Gd Wirakusuma dan Ni Md D. Ratnadi Pengaruh Skeptisisme...

diberikan oleh auditor yang kurang berpengalaman dan tidak memiliki kualifikasi pada kantor akuntan publik (Gaballa dan Zhou Ning, 2011). Auditor berpengalaman akan menghasilkan kualitas audit yang lebih baik, karena mampu mendeteksi dan menemukan penyebab terjadinya kecurangan dalam laporan keuangan (Bawono dan Singgih, 2011).

Sikap seorang individu, salah satunya dapat ditentukan melalui tipe kepribadian yang dimiliki seorang auditor, termasuk sikap skeptis. Semakin tinggi tingkat skeptis cenderung akan mempengaruhi auditor dalam pengambilan keputusan berdasarkan fakta yang ditemukan. Hal ini disebabkan tipe kepribadian auditor yang berpikiran logis. Novianty (2008)

Masih terbatasnya penelitian mengenai pendeteksian kecurangan memotivasi peneliti untuk meneliti kembali mengenai pendeteksian kecurangan. Dimana, dalam penelitian ini, peneliti menambahkan variabel etika, dan kompensasi untuk mengetahui seberapa besar faktor tersebut dapat meningkatkan kemampuan auditor dalam melakukan pendeteksian kecurangan. Etika merupakan bentuk tanggungjawab dan perilaku terhormat akuntan publik kepada publik, klien maupun sesama praktisi, bahkan jika harus mengorbankan kepentingan pribadi (Arens dkk., 2008). Akuntan publik yang mematuhi adanya aturan etika sebagai tanggungjawab terhadap publik, klien, maupun sesama praktisi akan memudahkannya dalam melakukan pendeteksian kecurangan (Louwers, 1997).

Peningkatan semangat kerja, motivasi serta kinerja karyawan dapat dipengaruhi oleh pemberian kompensasi yang tepat melalui kebijakan strategis perusahaan. Kinerja karyawan dipengaruhi oleh pemberian kompensasi (Hamdan 
dan Setiawan, 2014). Perusahaan yang memberikan kompensasi yang tepat untuk karyawannya akan meningkatkan motivasi karyawannya sehingga karyawan memiliki prestasi yang terlihat dari kualitas kerja yang lebih baik. Jadi semakin besar kompensasi yang diterima oleh auditor akan meningkatkan motivasi dan kinerja serta kemampuannya saat melakukan pendeteksian kecurangan (fraud), sehingga akan meningkatkan kualitas kerja dari auditor. Penelitian ini betujuan untuk memperoleh bukti empiris pengaruh skeptisisme profesional, etika, tipe kepribadian, kompensasi, dan pengalaman pada pendeteksian kecurangan. Hasil penelitian diharapkan mampu menambah informasi, wawasan, dan pengetahuan bagi pembaca maupun peneliti selanjutnya tentang teori atribusi mengenai pengaruh skeptisisme profesional, etika, tipe kepribadian, kompensasi dan pengalaman auditor pada pendeteksian kecurangan, serta diharapkan juga dapat memberikan saran dan masukan untuk KAP agar dapat menentukan hal apa saja yang dapat dilakukan dalam peningkatan kemampuan auditornya melakukan pendeteksian kecurangan.

\section{Kajian Pustaka}

Heider menyatakan perilaku seseorang dapat dijelaskan dengan teori atribusi. Heider mengembangkan teori ini dengan memberikan argumentasi bahwa kombinasi dari kekuatan internal (internal forces) dan kekuatan eksternal (external forces) yang menentukan perilaku suatu individu. Kinerja serta perilaku seseorang dapat dipengaruhi oleh kemampuannya secara personal yang berasal dari kekuatan internal yang dimiliki oleh seseorang misalnya seperti sifat, karakter, sikap, kemampuan, keahlian maupun usaha. Sedangkan, faktor-faktor 
Kd. Gita A.S., Md Gd Wirakusuma dan Ni Md D. Ratnadi Pengaruh Skeptisisme...

yang berasal dari luar kendali individu merupakan kekuatan eksternal seseorang seperti misalnya tekanan situasi, kesulitan atau keberuntungan dalam pekerjaan.

Peneliti menggunakan teori atribusi dengan melakukan pengujian secara statistik untuk memperoleh bukti empiris variabel-variabel yang mempengaruhi pendeteksian kecurangan. Baik buruknya kemampuan seorang auditor dalam mendeteksi kecurangan, diduga pada karakteristik dalam personal auditor maupun dari luar personal auditor. Tidaklah mudah bagi seorang auditor dalam melakukan pendeteksian kecurangan (Koroy, 2008). Mui (2010) berpendapat pendeteksian kecurangan merupakan aktivitas tidak terstuktur yang dilakukan auditor untuk mendapatkan informasi tambahan dari berbagai sumber. Auditor yang dapat menjelaskan ketidakwajaran dari laporan keuangan perusahaan dengan proses identifikasi dan membuktikan kecurangan yang ada adalah kemampuan dan kualitas yang ditunjukkan oleh seorang auditor (Sucipto, 2007). Keterampilan teknis, kemampuan bekerja didalam sebuah tim dan kemampuan menasehati adalah beberapa kemampuan yang harus dimiliki auditor agar dapat mendukung auditor dalam melakukan pendeteksian kecurangan.

Karakteristik personal auditor merupakan salah satu faktor internal yang memacu individu dalam beraktivitas. Karakteristik personal meliputi skeptisisme profesional yang dimiliki oleh seorang auditor. Pilihan dalam memenuhi kewajiban profesional auditor untuk mencegah konsekuensi yang dapat merugikan dari perilaku orang lain merupakan skeptisisme profesional seorang auditor. Seorang auditor yang memiliki skeptisisme profesional diasumsikan dapat mendeteksi kecurangan dengan baik apabila dibandingkan dengan auditor yang 
tidak memiliki skeptisisme profesional. Auditor yang memiliki skeptisisme profesional yang baik tidak akan mudah mempercayai bukti audit yang kurang layak atau tidak lengkap selama proses audit berlangsung. Hurtt (2010) menggambarkan bahwa skeptisisme profesional merupakan karakteristik individual multi-dimensi. Sebagai karakteristik individual, skeptisisme profesional dapat berbentuk sifat bawaan masing-masing (trait), yakni aspek yang stabil dan bertahan lama dalam diri seseorang dan juga situasional (state), yaitu kondisi sementara yang disebabkan oleh situasi tertentu. Skeptisisme merupakan manifestasi dari obyektivitas.

Etika, tipe kepribadian, maupun pengalaman merupakan atribut personal yang dimiliki oleh seorang auditor. Peraturan dan norma yang mengendalikan perilaku manusia, baik yang diharuskan maupun tidak dan dipatuhi oleh masyarakat maupun profesi disebut etika (Maryani dan Ludigdo, 2001). Etika Profesi merupakan nilai atau peraturan terhadap perilaku yang diterima dan diterapkan oleh profesi akuntan yang meliputi kecakapan profesional, tanggung jawab, kepribadian dan penafsiran, pelaksanaan kode etik dan penyempurnaan kode etik (Kusuma, 2012).

Selanjutnya kepribadian merupakan tingkah laku seseorang ketika berinteraksi dengan orang lain. Terdapat dua faktor utama terbentuknya kepribadian seseorang, dimana (1) faktor keturunan (genetik) merupakan dasar terbentuknya kepribadian seseorang, dan (2) faktor lingkungan, dimana berdasarkan kawasan atau tempat seseorang dibesarkan. Teori Myers Briggs menjelaskan bahwa auditor dengan kombinasi tipe kepribadian Sensing-Thinking 
Kd. Gita A.S., Md Gd Wirakusuma dan Ni Md D. Ratnadi Pengaruh Skeptisisme...

(ST) dan Intuition-Thinking (NT) biasanya berpikir logis dalam mengambil sebuah keputusan dengan mempertimbangkan seluruh fakta yang didapat untuk mendukung keputusannya. Auditor dengan tipe kepribadian ini juga meningkatkan tingkat pendeteksiannya ketika menemui indikasi kecuranga. Auditor yang berpengalaman diasumsikan lebih dapat mendeteksi kecurangan dibandingkan dengan yang kurang berpengalaman. Hal ini karena teknis maupun psikis seseorang dibentuk oleh pengalaman yang dimiliki.

Auditor yang pernah memiliki pengalaman kurang baik cenderung akan lebih berhati-hati ketika melaksanakan audit berikutnya. Mereka biasanya mengambil sikap untuk dapat menjalankan tugas dengan lebih baik untuk dapat mengetahui dan menemukan serta mengungkapkan (audit finding) yang dapat meningkatkan kualitas audit. Auditor yang tidak memiliki kualifikasi terhadap profesinya, ketika bekerja pada kantor akuntan publik cenderung memberikan dampak negatif terhadap kantor akuntan publik tersebut. Auditor dengan pengalaman banyak, memiliki kemampuan mendeteksi kekeliruan atau kecurangan dalam laporan keuangan, dan dapat menjelaskan temuannya dengan akurat, dibandingkan auditor pengalamannya kurang (Libby dan Frederick, 1990).

Selain karakteristik personal auditor, ada faktor lain diluar personal auditor yang berpengaruh pada kualitas audit yaitu kompensasi yang diterima auditor dalam menyelesaikan penugasan auditnya. Pemberian kompensasi adalah salah satu faktor diluar personal auditor yang berpengaruh pada kemampuan auditor dalam mendeteksi kecurangan. Peningkatan kinerja, motivasi, dan prestasi karyawan berhubungan dengan kebijakan strategis perusahaan dalam menetapkan 
kompensasi karyawan. Bila formulasi kebijakan terhadap kompensasi cermat, dalam sudut pandang adil dan layak maka dapat dipastikan kepuasan kerja karyawan akan tercapai, dan tujuan dari perusahaan terealisasi. Sebaliknya, akan terjadi keluhan, penurunan kinerja maupun ketidakpuasan kerja karyawan karena tidak terpenuhinya keadilan dan kelayakan kompensasi karyawan (Dharmawan, 2011). Sopiah (2013) menyatakan bahwa, kepuasan kerja merupakan faktor utama terbentuknya disiplin, moral dan kinerja karyawan yang membantu terwujudnya kepuasan kerja.

\section{Hipotesis Penelitian}

Teori atribusi merupakan pengintepretasian suatu kejadian, argumen, atau dampak suatu perilaku yang ditentukan kombinasi faktor internal dan faktor eksternal. Aktivitas yang dilakukan oleh suatu individu didorong oleh faktor internal yang dimiliki individu tersebut. Skeptisisme profesional, tipe kepribadian, etika, dan pengalaman auditor merupakan bagian dari karakteristik personal.

Pendeteksian kecurangan mendorong auditor untuk mencari bukti-bukti yang layak dan relevan. Fullerton dan Durtschi (2004) menyatakan Jika dalam menjalankan prosedur audit kemungkinan terdapat praktek kecurangan, maka auditor dengan skeptisisme tinggi akan melakukan peningkatan pendeteksian kecurangan dengan mencari informasi tambahan sebanyak mungkin. Berdasarkan fenoma yang didapat, penulis berasumsi, auditor dengan skeptisisme profesional tinggi akan melakukan peningkatan pendeteksian kecurangan, daripada auditor 
Kd. Gita A.S., Md Gd Wirakusuma dan Ni Md D. Ratnadi Pengaruh Skeptisisme...

yang memiliki skeptisisme professional rendah. Oleh karena itu, hipotesis yang diajukan yaitu:

$\mathrm{H}_{1}$ : Skeptisisme profesional berpengaruh positif pada pendeteksian kecurangan.

Etika merupakan bagian dari internal force yang mempengaruhi perilaku auditor dalam bertindak. Untuk memudahkan auditor dalam mendeteksi kecurangan, etika seorang auditor sangat diutamakan sebagai bentuk tanggungjawab kepada klien, sesama praktisi, publik, termasuk perilaku terhormat, atau bahkan melakukan pengorbanan atas kepentingan pribadi (Louwers, 1997). Khadilah dkk., (2015), menyatakan etika yang dimiliki auditor saat mengaudit laporan dapat mempengaruhi hasil audit menjadi lebih berkualitas. Kualitas dari laporan keuangan yang diaudit dapat dipengaruhi oleh etika yang dimiliki auditor (Ionescu 2011). Auditor yang beretika memiliki integritas dan objektivitas dalam melakukan pekerjaannya, sehingga mampu mendeteksi kecurangan dalam mengaudit laporan keuangan kliennya. Hasanah (2010) menyatakan penerapan aturan etika berpengaruh positif terhadap pendeteksian kecurangan. Berdasarkan fenomena penelitian sebelumnya, maka hipotesis kedua dirumuskan sebagai berikut.

$\mathrm{H}_{2}$ : Etika berpengaruh positif pada pendeteksian kecurangan.

Tipe kepribadian termasuk dalam interal forces yaitu faktor-faktor yang berasal dari dalam diri seseorang/ individu akan kemampuannya secara personal mampu memengaruhi kinerja serta perilakunya, sehingga tipe kepribadian auditor dapat memperngaruhi perilaku auditor dalam bertindak. Penentuan tipe 
kepribadian dalam penelitian ini menggunakan Myers Briggs Type Indicator (MBTI) yang memperkenalkan 16 macam kepribadian seseorang yang merupakan kombinasi dari empat pasang preferensi manusia. Berdasarkan teori Myers Briggs, Auditor dengan tipe kepribadiaan kombinasi ST dan NT memiliki pemikiran yang lebih logis dan selalu mempertimbangkan bukti audit yang ada untuk membuat dan mendukung keputusan yang dibuat. Penelitian Novianty (2008) telah membuktikan bahwa auditor dengan skeptisisme profesional yang lebih tinggi merupakan auditor yang memiliki tipe kepribadian kombinasi ST dan NT dibandingkan auditor dengan tipe kepribadian lainnya. Sehingga auditor dengan tipe kepribadian ST dan NT dapat melakukan pendeteksian kecurangan dengan lebih baik dibandingkan auditor dengan tipe kepribadian lainnya. Dengan demikian, berikut ini hipotesis ketiga yang dapat dirumuskan.

$\mathrm{H}_{3}$ : Tipe kepribadian berpengaruh pada pendeteksian kecurangan Kekuatan eksternal merupakan faktor-faktor yang berasal dari luar kendali individu seperti tekanan situasi. Kompensasi yang mempengaruhi perilaku auditor merupakan faktor eksternal. Kompensasi merupakan balas jasa yang perusahaan berikan pada karyawan atas pekerjaan dan tanggungjawab dengan harapan kinerja karyawan yang maksimal (Suseno dkk., 2014). Auditor akan termotivasi untuk bekerja lebih rajin karena kompensasi yang diberikan kantor akuntan publik sehingga kualitas audit yang dihasilkan lebih baik. Berdasarkan konsep tersebut, peneliti menduga bahwa semakin besar kompensasi yang diterima oleh seorang auditor akan meningkatkan kinerja dan kemampuan auditor melakukan 
Kd. Gita A.S., Md Gd Wirakusuma dan Ni Md D. Ratnadi Pengaruh Skeptisisme...

pendeteksian kecurangan. Dengan demikian, berikut ini merupakan hipotesis keempat yang dapat dirumuskan.

$\mathrm{H}_{4}$ : Kompensasi berpengaruh positif pada pendeteksian kecurangan.

Pengalaman merupakan internal force yang mempengaruhi perilaku auditor dalam bertindak. Pengalaman adalah lamanya waktu yang dihabiskan individu untuk berkarya dan menerapkan keahliannya di masyarakat (Noviari dkk., 2005). Penelitian Noviyani dan Bandi (2002), Tirta dan Sholihin (2004), serta Mui (2010) menyatakan pendeteksian kecurangan dan kesalahan yang dilakukan oleh auditor yang berpengalaman akan menghasilkan hasil yang lebih baik, daripada auditor yang tidak memiliki pengalaman. Dengan demikian, berikut ini hipotesis kelima yang dapat dirumuskan:

$\mathrm{H}_{5}$ : Pengalaman berpengaruh positif pada pendeteksian kecurangan.

\section{METODE PENELITIAN}

Penelitian ini dilakukan di Kantor Akuntan Publik yang berada di Wilayah Bali dan terdaftar pada Institut Akuntan Publik Indonesia 2016. Pertanyaan pertanyaan dalam kuesionar merupakan data kualitatif yang nantinya akan di kuantitatifkan dengan menggunakan skala likert yang mengaju pada variabel penelitian.

Peneliti menggunakan seluruh auditor yang bekerja pada Kantor Akuntan Publik di Bali. Sampel diambil dengan menggunakan teknik purposive sampling dengan kriteria sebagai berikut,

1) Auditor yang pernah melakukan audit investigatif. 
2) Auditor pernah ditugaskan dalam pekerjaan lapangan.

Berdasarkan kriteria tersebut, sampel penelitian yang diperoleh sebanyak 66 orang auditor. Pendeteksian kecurangan merupakan dependent variable penelitian ini yang diukur dengan menggunakan pernyataan-pernyataan mengenai gejala kecurangan (fraud symptoms) yang dikembangkan oleh Fullerton dan Durtschi (2004). Pernyataan yang digunakan sebanyak 10 item pernyataan, terkait dengan gejala kecurangan terkait dengan lingkungan perusahaan dan catatan keuangan dan praktek akuntansi

Penelitian ini memiliki lima variabel bebas yang terdiri dari skeptisisme profesional, etika, tipe kepribadian, kompensasi, dan pengalaman yang dijelaskan sebagai berikut.

1) Skeptisisme Profesional

Skeptisisme profesional merupakan sikap yang mencakup pikiran yang selalu mempertanyakan dan melakukan evaluasi secara kritis bukti audit (SPAP, 2011). Auditor tidak boleh menganggap bahwa manajemen adalah tidak jujur, namun juga tidak boleh menganggap bahwa kejujuran manajemen tidak dipertanyakan lagi. Skeptisisme profesional diukur dengan menggunakan model Hurtt, Eining, dan Plumlee (HEP) yang terdiri dari 15 item pernyataan. Model HEP mengukur skeptisisme profesional berdasarkan enam karakteristik sebagai indikatornya. Tiga karakterisktik yang pertama terkait dengan pengujian bukti audit, meliputi: questioning mind, suspension of 
Kd. Gita A.S., Md Gd Wirakusuma dan Ni Md D. Ratnadi Pengaruh Skeptisisme...

judgment, dan search for knowledge. Karakteristik keempat terkait dengan pemahaman bukti audit, yaitu: interpersonal understanding. Dua karakteristik berikutnya terkait dengan inisiatif seseorang untuk bersikap skeptis berdasarkan bukti yang diperolehnya, meliputi: self-confidence, dan selfdetermination.

2) Etika

Etika adalah seperangkat aturan atau norma atau pedoman yang mengatur perilaku manusia, baik yang harus dilakukan maupun yang harus ditinggalkan yang dianut oleh sekelompok atau segolongan manusia atau masyarakat atau profesi (Maryani dan Ludigdo, 2001). Finn et al. (1994) menyatakan bahwa indikator dari etika adalah peluang untuk berperilaku yang tidak etis, frekuensi perilaku yang tidak etis, dan tindakan partner/atasan atas perilaku tidak etis karyawan/ auditor saat melaksanakan penugasannya. Pengukuran etika $\left(\mathrm{X}_{2}\right)$ menggunakan 7 item pernyataan yang digunakan oleh Finn et al. (1994) dengan melakukan modifikasi kuesioner. Pernyataan dalam kuesioner terdiri dari pernyataan positif dan pernyataan negatif.

3) Tipe Kepribadian

Kepribadian (personality) didefinisikan oleh Gordon Allport dalam Novianty (2008) sebagai organisasi organik dalam individu yang memiliki sistem psikologis yang menentukan penyesuaian uniknya terhadap lingkungannya. Jadi, kepribadian merupakan cara - cara unik yang ditempuh individu dalam bereaksi dan berinteraksi dengan orang lain. Tipe Kepribadian dalam penelitian ini diukur dengan Myers-Briggs Type Indicator. Novianty (2008) 
dalam penelitiannya mengklasfikasikan tipe kepribadian menjadi dua kelompok, yaitu tipe kepribadian ST (Sensing-Thinking) dan NT (IntuitionThinking). Auditor dengan kombinasi tipe kepribadian ST dan NT diberi nilai 1 dan auditor dengan tipe kepribadian selain ST dan NT diberi nilai 0.

4) Kompensasi

Seluruh balas jasa yang diberikan perusahaan pada karyawan baik berupa uang, barang ataupun kenikmatan yang diberikan atas kinerja karyawan yang dilakukan untuk perusahaan adalah kompensasi (Gorda, 2006:190). Pengukuran kompensasi memiliki beberapa indicator, yaitu gaji, tunjangan, insentif, pelatihan, dan penghargaan (Dharmawan, 2011). Pengukuran kompensasi menggunakan 8 item pernyataan yang digunakan oleh Dharmawan (2011) dan dilakukan modifikasi atas pernyataan dalam kuesioner.

5) Pengalaman

Waktu yang dihabiskan seseorang untuk berkaya dalam menerapkan kemampuannya di masyarakat merupakan pengalaman yang dimiliki suatu individu. (Noviari, dkk, 2005). Pengalaman audit diukur berdasarkan 4 indikator nyang terdiri dari lamanya bekerja sebagai auditor, banyaknya pelatihan yang pernah diikuti, jabatan auditor yang dikembangkan (Gusnardi, 2003).

Dalam penelitian ini peneliti menggunakan skala likert 1 sampai 4, dengan pertimbangan agar mendapatkan pandangan atau pendapat auditor yang lebih terperinci mengenai pernyataan yang disajikan didalam kuesioner. Skala likert ini 
Kd. Gita A.S., Md Gd Wirakusuma dan Ni Md D. Ratnadi Pengaruh Skeptisisme...

mengacu pada modifikasi yang dilakukan Hadi (1991) untuk beberapa alasan, yaitu: multi interpretable, central tendency effect bagi auditor yang memiliki keraguan dalam menanggapi pernyataan, dan akan menghilangkan banyak informasi dari para auditor jika disediakan jawaban tengah.

Analisis regresi linear berganda dipilih untuk memecahkan masalah penelitian melalui program Statistical Package for Social Science (SPSS). Terdapat beberapa tahap analisis yang perlu dilakukan yaitu: uji instrument, perumusan model analisis regresi linear berganda, uji kelayakan model (Uji F), dan uji parsial (Uji t).

\section{HASIL DAN PEMBAHASAN}

Pengaruh masing - masing variabel dapat diketahui melalui hasil analisis regresi linear berganda. Namun, terlebih dulu perlu dilakukan uji instrumen yang terdiri dari uji validitas dan reliabilitas, serta uji asumsi klasik yang terdiri dari uji normalitas, uji multikolinearitas, dan uji heteroskedastisitas.

Instrumen dalam penelitian ini valid karena seluruh nilai koefisien korelasi dari instrumen ini lebih besar dari 0,3, sehingga instrumen ini dapat mengukur apa yang seharusnya dapat diukur. Hasil uji reliabilitas instrument yang menggunakan nilai Cronbach Alpha menunjukkan seluruh nilai koefisien dari instrument ini reliabel karena lebih besar dari 0,6. Data dalam penelitian ini berdistribusi normal yang ditunjukkan oleh nilai Asymp. Sig (2-tailed) sebesar $0.422>0,05$. Model 
regresi tidak mengandung gejala multikolinearitas yang ditunjukkan oleh nilai VIF masing - masing variabel bebas $<10$ dan nilai tolerance $>0,1$. Untuk mengetahui model regresi terbebas dari gejala heteroskedastisitas dilakukan dengan menggunakan uji Glejser yang menunjukkan bahwa nilai signifikansi setiap variabel bebas $>0.05$ yang artinya gejala heteroskedastisitas tidak terdapat dalam model regresi yang digunakan. Setelah uji instrumen dan uji asumsi klasik dilakukan, maka model regresi dapat digunakan untuk melakukan pengujian terhadap hipotesis yang telah dirumuskan. Adapun hasil analisis dapat ditunjukkan pada Tabel 1.

\section{Tabel 1.}

Rangkuman Hasil Analisis Regresi Linear Berganda

\begin{tabular}{lccc}
\hline \multicolumn{1}{c}{ Nama Variabel } & Koefisien Regresi & t-test & Sig. t \\
\hline Skeptisme Profesional & 0,325 & 2,822 & 0,006 \\
Etika & 0,260 & 3,082 & 0,003 \\
Tipe Kepribadian & 0,041 & 0,328 & 0,744 \\
Kompensasi & 0,245 & 2,876 & 0,006 \\
Pengalaman & 0,212 & 2,092 & 0,041 \\
Konstanta & & & 0,353 \\
R square & & & 0,586 \\
Adjusted Rsquare & & & 0,551 \\
F $_{\text {hitung }}$ & & & 16,958 \\
$\mathrm{~F}_{\text {sig }}$ & & & 0,000 \\
\hline Sumber: SPSS & &
\end{tabular}

Tabel 1. telah menyajikan nilai koefisien regresi dari variabel skeptisisme profesional, etika, tipe kepribadian, kompensasi, dan pengalaman maka diperoleh persamaan linier berganda sebagai berikut.

$$
\begin{aligned}
\mathrm{PK}= & 0,353+0,325(\mathrm{SP})+0,260(\mathrm{ET})+0,041(\mathrm{TP})+0,245(\mathrm{KM})+0,212 \\
& (\mathrm{PN})+\mathrm{e}
\end{aligned}
$$


Kd. Gita A.S., Md Gd Wirakusuma dan Ni Md D. Ratnadi Pengaruh Skeptisisme...

Kemampuan model dalam menerangkan variasi variabel dependen dapat diketahui melalui nilai koefisien determinasi (adjusted $R$ square). Nilai koefisien determinasi adalah diantara nol dan satu. Tabel 1. menunjukkan nilai Adjusted $R$ Square sebesar 0.551. Hal ini berarti sebesar 55,1 persen variabel dependen pendeteksian kecurangan dapat dijelaskan oleh variabel independen yaitu skeptisme profesional, etika, tipe kepribadian, kompensasi, dan pengalaman. Sisanya 44,9 persen dijelaskan oleh variabel lain yang tidak dimasukkan dalam model penelitian.

Pengujian terhadap fit atau tidaknya suatu model regresi dapat diketahui melalui uji F. Fit atau tidaknya suatu model regresi dapat dilihat dari nilai signifikansi yang lebih besar dari $\alpha$, yang menunjukkan model regresi yang digunakan tidak fit. Table 1. Menunjukkan nilai Sig. F sebesar 0,000<0,05, yang berarti model regresi layak digunakan dalam penelitian ini.

Untuk melihat pengaruh secara parsial dari variabel skeptisisme profesional, etika, tipe kepribadian, kompensasi dan pengalaman pada variabel pendeteksian kecurangan, maka dilakukan uji hipotesis yaitu uji t. Membandingkan tingkat signifikansi dengan tingkat kesalahan $(\alpha)$ sebesar 5\% merupakan cara yang dilakukan untuk menguji hipotesis penelitian. Skeptisisme professional memiliki pengaruh positif pada pendeteksian kecurangan yang dinyatakan dalam hipotesis pertama. Nilai koefisien beta $\left(\beta_{1}\right)$ sebesar 0,325 dengan tingkat signifikansi 0,006 yang lebih kecil dari $\alpha=0,05$ yang berarti bahwa $\mathrm{H}_{1}$ diterima. Dengan demikian hasil uji hipotesis menunjukkan bahwa skeptisisme profesional berpengaruh positif pada pendeteksian kecurangan. 
Skeptisme professional merupakan salah satu karaktersitik personal yang dimiliki oleh auditor. Hasil penelitian ini sejalan dengan penelitian Hasanah (2010) dan Nasution dan Fitiany (2012) yang menyatakan bahwa semakin tinggi tingkat skeptisisme profesional seseorang akan dapat mendeteksi kecurangan dengan lebih baik jika menemukan gejala kecurangan daripada auditor yang memilik skeptisisme profesional rendah. Agar dapat melakukan pendeteksian kecurangan dan terhindar dari kegagalan audit, auditor harus memiliki skeptisisme profesional dalam setiap penugasan audit yang dilakukan.

Auditor yang lebih skeptis akan mampu melakukan pendeteksian kecurangan pada tahap perencanaan audit, dan akan meningkatkan pendeteksiannya pada tahap audit berikutnya. (Carpenter, Durtschi, dan Gaynor, 2002). Auditor dengan skeptisisme profesional yang baik tidak akan mudah mempercayai bukti audit yang ditemukan selama proses audit untuk memastikan tidak terjadinya kecurangan dalam laporan keuangan yang diaudit olehnya. Audit yang dirancang dengan skeptisisme profesional yang tinggi akan dapat memberikan keyakinan yang memadai untuk mendeteksi adanya kecurangan maupun kesalahan dalam laporan keuangan yang bersifat material (Silalahi, 2013).

Hipotesis kedua menyatakan bahwa etika berpengaruh positif pada pendeteksian kecurangan. Tabel 1. menunjukkan bahwa nilai koefisien beta $\left(\beta_{2}\right)$ adalah 0,260 dengan tingkat signifikansi 0,003 yang lebih kecil dari $\alpha=0,05$ yang berarti bahwa $\mathrm{H}_{2}$ diterima. Dengan demikian etika berpengaruh positif pada pendeteksian kecurangan yang ditunjukkan dari hasil uji hipotesis. Kode etik 
Kd. Gita A.S., Md Gd Wirakusuma dan Ni Md D. Ratnadi Pengaruh Skeptisisme...

profesi merupakan salah satu hal yang harus dipatuhi oleh seorang akuntan publik selain standar audit (Agusti dan Nastia, 2013). Kode etik profesi salah satunya mencakup tentang kompentensi, perilaku profesional, standar teknis, serta tanggung jawab profesi. Secara tertulis etika dinyatakan sebagai kode etik. Sehingga, dengan mentaati aturan etika saat menjalankan tugasnya, auditor akan dimudahkan dalam melakukan pendeteksian kecurangan. Peran kunci dalam semua area profesi akuntan dimainkan oleh kesadaran akan aturan etika yang telah ditetapkan (Louwers, 1997). Seorang auditor memerlukan kesadaran etis, bahwa tugas melakukan audit laporan keuangan merupakan tugas penting, karena akan berdampak pada kepercayaan masyarakat dan pengambil keputusan yang telah menaruh kepercayaan pada auditor untuk menilai kewajaran laporan keuangan suatu perusahaan dan menyadari pentingnya jasa yang mereka berikan. Auditor yang beretika memiliki integritas dan objektivitas dalam melakukan pekerjaannya, sehingga mampu mendeteksi adanya kecurangan dalam laporan keuangan kliennya, serta dapat menghasilkan informasi yang berkualitas.

Hipotesis ketiga menyatakan bahwa tipe kepribadian tidak berpengaruh pada pendeteksian kecurangan. Tabel 1. menunjukkan bahwa nilai koefisien beta $\left(\beta_{3}\right)$ adalah 0,041 dengan tingkat signifikansi 0,744 yang lebih besar dari $\alpha=0,05$ yang berarti bahwa $\mathrm{H}_{3}$ ditolak. Dengan demikian hasil uji hipotesis menunjukkan bahwa tipe kepribadian tidak berpengaruh pada pendeteksian kecurangan. Hasil penelitian ini serupa sebelumnya yang terlah ditemukan oleh Supriyanto (2014) dan Faradina (2016) yang menyatakan bahwa baik auditor dengan tipe kepribadian kombinasi Sensing-Thinking (ST) dan Intuition-Thinking (NT) dan 
auditor dengan tipe kepribadian lainnya memiliki kemampuan mendeteksi kecurangan jika menemukan adanya gejala kecurangan. Nasution dan Fitriany (2012) juga menyatakan auditor dengan tipe kepribadian kombinasi ST dan NT dan auditor dengan tipe kepribadian lainnya tidak memiliki perbedaan dalam meningkatkan kemampuan pendeteksian kecurangannya. Hal ini dikarenakan ketika auditor melaksanakan tugas audit kelapangan, mereka telah berpedoman dengan mengikuti prosedur audit yang telah ditetapkan. Sehingga apapun tipe kepribadian yang dimiliki oleh seorang auditor baik itu tipe kepribadian kombinasi ST dan NT maupun auditor dengan tipe kepribadian lainnya tidak akan mampu mempengaruhi kinerjanya dalam melakukan pedeteksian kecurangan karena mereka dituntut untuk profesional dalam menjalakan tugasnya apapun tipe kepribadian yang dimiliki oleh seorang auditor (Nurutami, 2014).

Hipotesis keempat menyatakan bahwa kompensasi berpengaruh positif pada pendeteksian kecurangan. Tabel 1. menunjukkan bahwa nilai koefisien beta $\left(\beta_{4}\right)$ adalah 0,245 dengan tingkat signifikansi 0,006 yang lebih kecil dari $\alpha=0,05$ yang berarti bahwa $\mathrm{H}_{4}$ diterima. Dengan demikian hasil uji hipotesis menunjukkan bahwa kompensasi berpengaruh positif pada pendeteksian kecurangan. Kualitas kerja seseorang cenderung dipengaruhi oleh besarnya kompensasi yang diterima seseorang (Zeng dan Cullinan, 2010). Kompensasi terdiri dalam bentuk financial dan nonfinancial yang berpengaruh pada kinerja seseorang. Kualitas kerja karyawan yang baik mencermikan karyawan tersebut memiliki prestasi. Semakin besar kompensasi yang diterima seorang auditor akan meningkatkan kinerja dan 
Kd. Gita A.S., Md Gd Wirakusuma dan Ni Md D. Ratnadi Pengaruh Skeptisisme...

kemampuan auditor dalam mendeteksi adanya kecurangan, sehingga akan meningkatkan kualitas kerja dari auditor.

Hasil uji hipotesis menunjukan bahwa kompensasi berpengaruh terhadap pendeteksian kecurangan. Hasil ini memberikan pengaruh signifikan dimana jumlah kompensasi yang diberikan kantor akuntan publik memotivasi seorang auditor dalam bekerja lebih teliti dan bersemangat. Ketika jumlah kompensasi yang diberikan besar, tentunya akan berpengaruh terhadap kinerja seorang auditor. Mereka cenderung akan lebih termotivasi dalam melakukan proses audit dan mampu mendeteksi adanya kecurangan dalam laporan keuangan yang diaudit. Hasil penelitian ini sesuai dengan penelitian Sopiah (2013) yang menyatakan bahwa variabel kompensasi terbukti memiliki pengaruh signifikan pada kepuasan kerja karyawan.

Hipotesis kelima menyatakan bahwa pengalaman berpengaruh positif pada pendeteksian kecurangan. Tabel 1. menunjukkan bahwa nilai koefisien beta $\left(\beta_{5}\right)$ adalah 0,212 dengan tingkat signifikansi 0,041 yang lebih kecil dari $\alpha=0,05$ yang berarti bahwa $\mathrm{H}_{5}$ diterima. Dengan demikian hasil uji hipotesis menunjukkan bahwa pengalaman berpengaruh positif pada pendeteksian kecurangan. Penelitian sebelumnya yang dilakukan oleh Noviyani dan Bandi (2002) dan didukung Tirta dan Solihin (2004) menemukan hal yang serupa, yang menyatakan bahwa pendeteksian kecurangan dan kesalahan yang dilakukan oleh auditor yang memiliki lebih banyak pengalaman akan menghasilkan hasil audit yang lebih baik, dibandingkan auditor yang tidak berpengalaman. Auditor yang berpengalaman diasumsikan dapat mendeteksi adanya kecurangan dengan lebih baik 
dibandingkan auditor yang belum berpengalaman. Hal ini karena baik secara teknis maupun psikis, keahlian seseorang akan dibentuk oleh pengalaman. Berbagai dugaan yang digunakan dalam menjelaskan temuan audit akan lebih banyak dihasilkan oleh auditor yang memiliki banyak pengalaman.

Auditor yang memiliki pengalaman akan menghasilkan kualitas audit yang lebih baik, karena mampu mendeteksi dan menemukan penyebab terjadinya kecurangan dalam laporan keuangan (Bawono dan Singgih, 2011). Seseorang yang melakukan pekerjaan yang sama berulang kali, akan meningkatkan pengalaman dan keterampilannya sehingga pekerjaan dapat diselesaikan dalam waktu yang lebih singkat (Rahmawati dan Usman, 2014). Auditor dengan pengalaman banyak, memiliki kemampuan mendeteksi kekeliruan atau kecurangan dalam laporan keuangan, dan dapat menjelaskan temuannya dengan akurat, dibandingkan auditor pengalamannya kurang (Libby dan Frederick, 1990).

\section{SIMPULAN DAN SARAN}

Penelitian ini menunjukkan skeptisisme profesional berpengaruh positif pada pendeteksian kecurangan. Seorang auditor dengan tingkat skeptisisme profesional yang lebih tinggi akan memiliki kemampuan dalam mendeteksi adanya kecurangan dalam pelaporan keuangan. Penelitian juga menunjukkan adanya pengaruh positif antara etika dan pendeteksian kecurangan. Auditor yang beretika memiliki integritas dan objektivitas dalam melakukan pekerjaannya, sehingga mampu mendeteksi adanya kecurangan dalam laporan keuangan kliennya. Selain itu, kompensasi juga memiliki pengaruh yang positif pada pendeteksian kecurangan. Semakin besar kompensasi yang diterima seorang auditor akan 
Kd. Gita A.S., Md Gd Wirakusuma dan Ni Md D. Ratnadi Pengaruh Skeptisisme...

meningkatkan kinerja, kemampuan serta motivasi auditor dalam melakukan pendeteksian kecurangan. Hasil penelitian juga menunjukkan pengalaman berpengaruh positif pada pendeteksian kecurangan. Kualitas audit yang berkualitas dihasilkan dari auditor yang memiliki lebih banyak pengalaman daripada auditor yang kurang berpengalaman karena dapat mendeteksi, memahami, dan menemukan penyebab terjadinya kecurangan dalam laporan keuangan. Disisi lain, tipe kepribadian tidak memiliki pengaruh pada pendeteksian kecurangan. Tipe kepribadian kombinasi Sensing-Thingking dan Intuiton-Thinking dengan auditor dengan tipe kepribadian lainnya tidak menimbulkan perbedaan terhadap kemampuan pendeteksian kecurangan oleh auditor. Bagaimanapun tipe kepribadian auditor tidak akan mempengaruhi kinerja auditor dalam mendeteksi kecurangan karena telah memiliki pedoman dan dituntut profesional dalam menjalankan prosedur audit.

Auditor diharapkan mampu meningkatkan pengalaman dan pemahaman etika audit, karena tidak dapat dipungkiri auditor harus memiliki pengalaman dan pemahaman etika audit yang baik saat melakukan audit. Selain itu hasil penelitian ini diharapkan menjadi pertimbangan pihak Kantor Akuntan Publik (KAP) untuk membuat aturan dan pola kerja yang dapat meningkatkan skeptisisme profesional, etika, dan pengalaman yang dimiliki auditor. Selain itu KAP diharapkan mampu memberikan kompensasi yang cukup pada para auditornya untuk meningkatkan motivasi kerja auditor. Berdasarkan hasil penelitian nilai adjusted $\mathrm{R}^{2}$ penelitian ini sebesar 55,1 persen. hal ini menunjukkan bahwa masih ada variabel lain diluar model sebesar 44,9 persen yang dapat 
memengaruhi kemampuan pendeteksian kecurangan, sehingga diharapkan peneliti selanjutnya dapat mengamati faktor - faktor lain yang mempengaruhi kemampuan auditor dalam melakukan pendeteksian kecurangan. Penelitian ini merupakan aplikasi dari ilmu keperilakuan dengan menggunakan metode survei. Penelitian selanjutnya dapat menggunakan metode eksperimental guna menghasilkan validitas internal penelitian yang lebih baik untuk menunjukkan faktor - faktor yang mempengaruhi kemampuan pendeteksian kecurangan. Hasil penelitian ini hanya terbatas pada kesimpulan yang didasarkan pada persepsi dari auditor akuntan publik saja. Penelitian selanjutnya dapat melakukan perbandingan antara persepsi auditor akuntan publik dengan auditor Badan Pemeriksa Keuangan (BPK) terkait dengan pendeteksian kecurangan.

\section{REFERENSI}

Agusti, Restu dan Nastia Putri Pertiwi. 2013. Pengaruh Kompetensi, Independensi, dan Profeionalisme Terhadap Kualitas Audit (Studi Empiris Pada Kantor Akuntan Publik Se Sumatera). Jurnal Ekonomi. Volume 21, Nomor 3. September.

Arens, Alvin A. James L. Loebbecke. 2008. Auditing Pendekatan Terpadu. Jakarta: Salemba Empat.

Carpenter, Tina., Durtschi Cindy and Lisa Milici Gaynor. 2002. The Role of Experience in Professional Skepticism, Knowledge Acquisition, and Fraud Detection.

Dharmawan, I Made Yusa. 2011. Pengaruh Kompensasi dan Lingkungan Kerja Non Fisik Terhadap Disiplin dan Kinerja Karyawan Hotel Nikki Denpasar. Tesis. Universitas Udayana.

Faradina, Haura. 2016. Pengaruh Beban Kerja, Pengalaman Audit dan Tipe Kepribadian Terhadap Skeptisme Profesional dan Kemampuan Auditor Dalam Mendeteksi Kecurangan. JOM Fekon, 3 (1), 1235-1249. 
Kd. Gita A.S., Md Gd Wirakusuma dan Ni Md D. Ratnadi Pengaruh Skeptisisme...

Finn, Don W., Thomas, Paul, Munter dan Caslin, E. Mc., 1994. Ethical Perceptions of CPAs. Journal. Managerial Auditing Journal, Vol. 9 No. 1 p. 23 28.

Fransiska, Pusptita Inneke dan Fatmawati, Dewi. 2015. Pengaruh Skeptisme Profesional dan Skeptisme Situasional (Client-Specific Experience) Pada Keputusan Audit. Jurnal. Simposium Nasional Akuntansi XVIII. Medan.

Fullerton, Rosemary R., and Durtschi, Cindy. (2004). The Effect of Professional Skepticism on The Fraud Detection Skills of Internal Auditors. Working Paper Series. August 3, 2016. http://www.ssrn.com

Gaballa, Azza S.M dan Zhou Ning. 2011. An Analytical Study Off The Effect Of Experience: On The Performance Of the External Auditor. Journal. Research International Conference On Business and Economics, Vol. 1, p. 169-173.

Gusnardi. 2003. Analisis Perbandingan Faktor-faktor yang Mempengaruhi Judgment Penetapan Risiko Audit oleh Auditor yang Berpengalaman dan Auditor yang Belum Berpengalaman. Tesis. Universitas Padjadjaran. (Tidak Dipublikasikan).

Gusti, Maghfirah dan Syahril Ali. 2006. Hubungan Skeptisme Profesional Auditor dan Situasi Audit, Etika, Pengalaman serta Keahlian Audit dengan Ketepatan Pemberian Opini oleh Akuntan Publik. Jurnal. Simposium Nasional Akuntansi XI. Pontianak.

Hamdan, Ekshu dan Setiawan, Roy. 2014. Pengaruh Kompensasi Finansial dan Non Finansial Terhadap Kinerja Karyawan PT. Samudera Buana Persada. Jurnal. AGORA, Vol. 2, No. 1.

Hasanah, Sri. 2010. Pengaruh Penerapan Aturan Etika, Pengalaman, dan Skeptisme Profesional Auditor Terhadap Pendeteksian Kecurangan. Skripsi. Universitas Islam Negeri Syarif Hidayatullah.

Hurtt, R. K. 2010. Development a Scale to Measure Professional Skepticism. Journal. Auditing: A Journal of Practice\&Theory , 149-171.

Ionescu, Luminita. 2011. The Financial Crisis As A Failure Of Internal Audit. Journal. Economics, Management, and Financial Markets, Vol. 6, No. 2, pp: 833838.

Khadilah, Rizma R., Purnamasari, Pupung, dan Gunawan, Hendra. 2015. Pengaruh Time Budget Pressure, Pengalaman Auditor, Etika Auditor, dan Kompleksitas Audit Terhadap Kualitas Audit. Jurnal. Proseding Penelitian SPESIA, h: 236-243. 
Koroy, Tri Ramaraya. (2008). Pendeteksian Kecurangan (Fraud) Laporan Keuangan oleh Auditor Eksternal. Jurnal. Jurnal Akuntansi dan Keuangan Vol.10,No. 1, Mei 2008: 22-23.

Kusuma, Novanda Friska B. Aji. 2012. Pengaruh Profesionalisme Auditor, Etika Profesi, dan Pengalaman Auditor Terhadap Pertimbangan Tingkat Materialitas. Skripsi. Universitas Negeri Yogyakarta.

Libby, R. Dan Frederick, David M. 1990. Experience and Ability to Explain Audit Finding. Journal. Journal of Accounting Research, Vol. 28, No. 2 Autumn.

Maryani, T dan Ludigdo U. 2001. Survei Atas Faktor-Faktor Yang Mempengaruhi Sikap dan Perilaku Etis Akuntan. Jurnal. TEMA, Vol. II, No. 1, hal:49-62.

Mui, Grace Yanchi. 2010. Factors That Impact On Internal Auditors' Fraud Detection Capabilities - A Report For The Institute of Internal Auditors Australia. Journal. Center for Business Forensics HELP University Malaysia.

Nasution, Hafifah dan Fitriany. 2012. Pengaruh Beban Kerja, Pengalaman Audit, dan Tipe Kepribadian Pada Skeptisme Profesional dan Kemampuan Auditor Mendeteksi Kecurangan. Jurnal. Simposium Nasional Akuntansi XV. Banjarmasin.

Noviari, S., Merdekawati, T.E., dan Sudarsono, D.T.E. 2005. Hubungan Etika, Pengalaman, Ketaatan pada Standar Profesi, dan Akuntabilitas Profesional (Survey pada Akuntan Publik di DKI Jakarta). Jurnal. Proceeding Seminar Nasional PESAT, hal: 165-172.

Noviyani, Putri dan Bandi. 2002. Pengaruh Pengalaman dan Pelatihan Terhadap Struktur Pengetahuan Auditor Tentang Kekeliruan. Jurnal. Simposium Nasional Akuntansi V. Semarang.

Rahmawati dan Halim Usman. 2014. Pengaruh Beban Kerja dan Pengalaman Auditor dalam Mendeteksi Kecurangan. Jurnal. Jurnal Akuntansi \& Investasi, Vol. 15, No. 1. Januari 2014.

Silalahi, Sem Paulus. 2013. Pengaruh Etika, Kompetensi, Pengalaman Audit, dan Situasi Audit Terhadap Skeptisme Profesional Auditor. Jurnal. Jurnal Ekonomi, Volume 21, Nomor 3. September 2013.

Singgih, Elisha Muliani dan Bawono, Icuk Rangga. 2010. Pengaruh Independensi, pengalaman, Due Professional Care, dan Akuntabilitas Terhadap Kualitas Audit (Studi pada Auditor di KAP "Big Four" di Indonesia. Jurnal. Simposium Nasional Akuntansi XIII. Purwokerto. 
Kd. Gita A.S., Md Gd Wirakusuma dan Ni Md D. Ratnadi Pengaruh Skeptisisme...

Sopiah. 2013. The Effect of Compensation Toward Job Satisfaction and Job Performance of Outshourching Employees of Syariah Banks in Malang Indonesia. Journal. International Journal Learning and Development, Vol. 3, No. 2. ISSN 2164-4063.

Sucipto. 2007. Pengaruh Pengalaman Auditor Eksternal Dalam Mendeteksi Kecurangan. Skripsi. Universitas Diponegoro.

Supriyanto. 2014. Pengaruh Beban Kerja, Pengalaman Audit, Tipe Kepribadian, dan Skeptisme Profesional Pada Kemampuan Auditor Dalam Mendeteksi Kecurangan. Skripsi. Universitas Muhammadiyah Surakarta.

Suseno, Eta, Setyawan, Hamid, Djamhur, dan Ruhana, Ika. 2014. Pengaruh Kompensasi Finansial dan Non Finansial Terhadap Kinerja Karyawan (Studi pada Bank Rakyat Indonesia Cabang Jember). Jurnal. Jurnal Administrasi Bisnis, Vol. 8, No. 2.

Tirta, Rio., dan Sholihin, Mahfud. (2004). The Efect of Experience and TaskSpecific Knowledge on Auditors' Performance in Assessing A Fraud Case. Journal. JAAI, Vol. 8, No.1, 1-21.

Zeng, Xiaochuan dan Cullinan, Charles, P. 2010. Compensation/Audit Committee Overlap and The Design of Compensation Systems. International Journal of Disclosure and Governance, Vol. 7, pp: 136-152. 